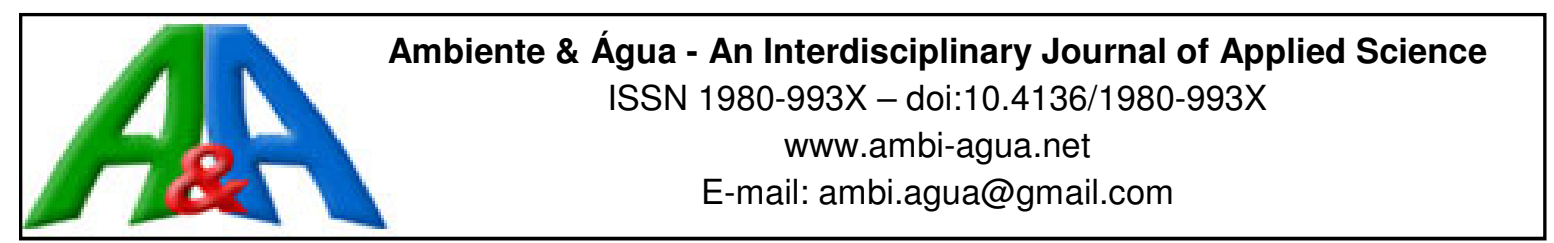

\title{
Advances in wastewater nitrogen removal by biological processes: state of the art review
}

\author{
doi:10.4136/ambi-agua.1772
}

Received: 06 Oct. 2015; Accepted: 28 Mar. 2016

\author{
Andrea G. Capodaglio ${ }^{1}$; Petr Hlavínek ${ }^{2}$; Massimo Raboni ${ }^{3 *}$ \\ ${ }^{1}$ University of Pavia (UNIPV), Pavia, PV, Italy \\ Department of Civil Engineering and Architecture \\ ${ }^{2}$ University of Technology, Brno, Czech Republic \\ ${ }^{3}$ University LIUC, Castellanza (VA), Italy \\ "Corresponding author: e-mail: mraboni@liuc.it, \\ capo@unipv.it, hlavinek.p@fce.vutbr.cz
}

\begin{abstract}
The paper summarizes the state-of-the-art of the most recent advances in biological nitrogen removal, including process design criteria and technological innovations. With reference to the Modified Ludzck Ettinger (MLE) process (pre-denitrification and nitrification in the activated sludge process), the most common nitrogen removal process used nowadays, a new design equation for the denitrification reactor based on specific denitrification rate (SDNR) has been proposed. In addition, factors influencing SDNR (DO in the anoxic reactor; hydrodynamic behavior) are analyzed, and technological solutions are proposed. Concerning technological advances, the paper presents a summary of various "deammonification" processes, better known by their patent names like ANAMMOX ${ }^{\circledR}$, DEMON $^{\circledR}, \mathrm{CANON}^{\circledR}$, ANITA $^{\circledR}$ and others. These processes have already found applications in the treatment of high-strength wastewater such as digested sludge liquor and landfill leachate. Among other emerging denitrification technologies, consideration is given to the Membrane Biofilm Reactors (MBfRs) that can be operated both in oxidation and reduction mode.
\end{abstract}

Keywords: biological processes, deammonification, denitrification, nitrogen removal.

\section{Avanços na remoção biológica de nitrogênio das águas residuais: uma revisão}

\section{RESUMO}

$\mathrm{O}$ artigo resume o estado da arte dos mais recentes avanços na remoção biológica de nitrogênio, incluindo os critérios para o cálculo do processo e as inovações tecnológicas. Em relação ao processo Ludzck Ettinger modificado (pré-desnitrificação, nitrificação, no sistema de lodo activados), o qual é amplamente utilizado na remoção biológica de nitrogênio, foi proposta uma nova equação para calcular o reactor de desnitrificação, com base na taxa de desnitrificação (SDNR-Specific Denitrification Rate). Além disso, foram analisados os fatores que influenciam o SDNR (oxigênio dissolvido no reator; comportamento hidrodinâmico do reator) e foram propostas as soluções tecnológicas. Quanto à evolução tecnológica, o artigo apresenta um resumo dos vários processos de remoção biológica de amônia, que são mais 
conhecidos com os nomes patenteados, tais como: ANAMMOX $^{\circledR}$, DEMON $^{\circledR}, \mathrm{CANON}^{\circledR}$, ANITA $^{\circledR}$ e outros. Estes processos já encontraram aplicações industriais no tratamento de águas residuais de alta concentração, tais como o licor de lodo digerido e o percolado de aterro sanitário. Entre as tecnologias emergentes de desnitrificação foram considerados os bioreatores com membranas (MBfR), os quais podem ser operados tanto na fase aeróbia quanto na fase anóxica.

Palavras-chave: desnitrificação, remoção biológica de amônia, remoção de nitrogênio.

\section{INTRODUCTION}

Nitrogen removal from wastewater can be achieved by means of physico-chemical or biological processes. As far as the former are concerned, many technologies are available, as discussed elsewhere (Raboni et al., 2013b; Capodaglio et al., 2015).

Biological processes for nitrogen removal are generally applied to the denitrification of municipal wastewaters, and often to food and beverage processing industries, tanneries, fertilizer and petrochemical plants, as well as extensive livestock farm wastewaters. At present, the dominant technology is pre-denitrification in activated sludge systems, where an anoxic stage (DEN) is located upstream of an aerobic oxidation-nitrification (OX-NIT) stage.

Research in this field is mainly focused on evaluating optimal sizing criteria for the denitrification reactor. One of the key factors is represented by dissolved oxygen (DO) inhibition on the denitrification rate; thus, technological improvements that can reduce DO presence in the anoxic stage are among the most relevant (Raboni et al., 2014a; Torretta et al., 2014; Urbini et al., 2015). Recent studies have highlighted the limits of denitrification efficiency in small communities' plants due to strong fluctuations of incoming loads (Raboni et al., 2013b). Equally important is the effect of the denitrification reactor hydrodynamic behavior on process performance (Raboni et al., 2015).

Among the most recent developments in biological denitrification, the "deammonification" process (better known by its patented versions ANAMMOX®, DEMON®, CANON®, ANITA® and others) carried out by aerobic ammonia-oxidizing bacteria capable of degrading ammonia to nitrogen, has already found widespread application in the treatment of high-strength wastewaters such as digested sludge liquor and landfill leachate (US-EPA, 2009; 2010).

\section{ADVANCES IN DESIGN OF DENITRIFICATION REACTORS IN ACTIVATED SLUDGE PLANTS}

\subsection{SDNR (Specific denitrification rate) for pre-denitrification design}

Design of biological pre-denitrification has been usually carried out on the basis of the denitrification rate $r_{D E N}$, represented by a zero-order kinetics (for both $\mathrm{NO}_{3}-\mathrm{N}$ and organic substrate) corrected for the effects of process temperature according to Arrhenius (Equation 1; Ekama, 2011):

$$
\left(r_{D E N}\right)_{T}=\left(r_{D E N}\right)_{20^{\circ} \mathrm{C}} \cdot \theta^{T-20}
$$

where:

$\left(r_{D E N}\right)_{20^{\circ} \mathrm{C}}$ is the denitrification rate at $20^{\circ} \mathrm{C}$ in denitrification tank (DEN), usually equal to $2.9 \div 3.0 \mathrm{gNO}_{3}-\mathrm{N} \mathrm{h}^{-1} \mathrm{kgMLVSS}^{-1}$ (Raboni et al., 2014b). This approach is still widely used nowadays; however, since it was observed that denitrification rates can be significantly reduced by the presence of DO, its inhibitory effect was taken into account by including an 
inhibition term $K^{\prime}{ }_{O} /\left(K^{\prime}{ }^{+}+D O\right)$ in $r_{D E N}$ expression (US-EPA, 2009; 2010) (Equation 2).

$$
r_{D E N}=\left(\frac{1-1.42 Y}{2.86}\right) \cdot\left(\frac{K \cdot S \cdot X}{K_{S}+S}\right) \cdot\left(\frac{N O_{3}-N}{K_{N}+N O_{3}-N}\right) \cdot\left(\frac{K_{O}^{\prime}}{K_{O}^{\prime}+D O}\right) \cdot \eta
$$

where:

$r_{D E N}$ is the denitrification rate $\left(\mathrm{NO}_{3}-\mathrm{N}\right.$ removal by dissimilation; $\left.\mathrm{mgNO}_{3}-\mathrm{N} \mathrm{L}^{-1} \mathrm{~h}^{-1}\right)$;

$Y$ is the heterotrophic bacteria synthesis yield ( $\mathrm{mgVSS} \mathrm{mg}^{-1}$ substrate consumed);

$K$ is the maximum specific rate of substrate utilization $\left(\mathrm{h}^{-1}\right)$;

$X$ is the biomass concentration (mgMLVSS $\left.\mathrm{L}^{-1}\right)$;

$S$ is the soluble degradable substrate concentration $\left(\mathrm{mg} \mathrm{L}^{-1}\right)$;

$K_{S}$ is the substrate utilization half-velocity coefficient $\left(\mathrm{mg} \mathrm{L}^{-1}\right)$;

$\mathrm{NO}_{3}-\mathrm{N}$ is the nitrate concentration, as $\mathrm{N}\left(\mathrm{mgNO}_{3}-\mathrm{N} \mathrm{L}^{-1}\right)$;

$K_{N}$ is the nitrate half-velocity coefficient $\left(\mathrm{mgNO}_{3}-\mathrm{N} \mathrm{L}^{-1}\right)$;

$K_{O}{ }_{O}$ is the $D O$ inhibition constant for nitrate reduction $\left(\mathrm{mgO}_{2} \mathrm{~L}^{-1}\right)$; and

$\eta$ is the fraction of heterotrophic bacteria that use nitrate in lieu of oxygen (dimensionless).

Tchobanoglous et al. (2003) proposed a similar equation, adding an assimilative (cell synthesis) term to the dissimilative one as Equation 3.

$$
r_{D E N}{ }^{\prime}=r_{D E N}+\left(\frac{N O_{3}-N}{K_{N}+N O_{3}-N}\right) \cdot\left(\frac{K_{O}^{\prime}}{K_{O}^{\prime}+D O}\right) \cdot\left(\frac{1.42}{2.86}\right) \cdot K_{d} \cdot X \cdot \eta
$$

where:

$K_{d}$ is the endogenous decay coefficient $\left(\mathrm{h}^{-1}\right)$.

$K^{\prime} O$ varies in a wide value range $\left(0.02-0.2 \mathrm{mg} \mathrm{L}^{-1}\right)$ depending on floc size and sludge structure (Tchobanoglous et al., 2003). In any case, the mere presence of $0.2 \mathrm{mgDO} \mathrm{L}^{-1}$ could theoretically induce a $40 \%$ decrease in denitrification, compared to uninhibited conditions (Tchobanoglous et al., 2003). Other studies showed the effects of inhibition (Oh and Silverstein, 1999; Plòsz et al., 2003); in particular, significant effects of DO inhibition at concentrations as low as $0.09 \mathrm{mg} \mathrm{L}^{-1}$, with up to $35 \%$ denitrification reduction, were observed (Oh and Silverstein, 1999).

For the practical calculation of the denitrification reactor volume a semi-empirical relationship (Equation 4; Tchobanoglous et al., 2003) was proposed, which correlates SDNR (Specific DeNitrification Rate) with the sludge load in DEN ( $F: M_{D E N}$; $\mathrm{gBOD}_{5}$ applied $\left.\mathrm{d}^{1} \mathrm{gMLVSS}^{-1}\right)$ :

$$
\operatorname{SDNR}_{20^{\circ} \mathrm{C}}=0.029+0.03 \cdot F: M_{D E N}\left(\text { at about } 20^{\circ} \mathrm{C}\right)
$$

where:

$$
\begin{aligned}
& S D N R=Q \cdot \triangle N O_{3}-N V_{D E N}^{-1} X_{D E N}^{-1}\left(\mathrm{gNO}_{3}-\mathrm{N} \mathrm{gMLVSS}^{-1} \mathrm{~d}^{-1}\right) \\
& V_{D E N} \text { is the DEN volume }\left(\mathrm{m}^{3}\right) ; \text { and } \\
& X_{D E N} \text { is the biomass concentration in DEN }\left(\mathrm{gMLVSS} \mathrm{m}^{-3}\right) \text {. }
\end{aligned}
$$


US-EPA (2010) proposes the same formula applying a correction factor to the F:M ratio in order to take into account the deviation of the active fraction of biomass in the mixed-liquor from the reference value (30\%). Values of SDNR observed in pre-anoxic reactors at full-scale installation range from 0.04 to $0.42 \mathrm{gNO}_{3}-\mathrm{N}$ gMLVSS$^{-1} \mathrm{~d}^{-1}$ (Tchobanoglous et al., 2003), while US-EPA (2010) reports a more narrow range, 0.05 to $0.15 \mathrm{gNO}_{3}-\mathrm{N} \mathrm{gMLVSS}^{-1} \mathrm{~d}^{-1}$ at $20^{\circ} \mathrm{C}$.

Recently, the strong dependence of $S D N R$ in DEN on DO and F: $\mathrm{M}_{\mathrm{DEN}}$ has been highlighted (Raboni et al., 2014b; Torretta et al., 2014). Experimental results, supported by theoretical evaluations, allowed the representation of $S D N R_{20^{\circ} \mathrm{C}}$ (Equation 5).

$$
S D N R_{20^{\circ} \mathrm{C}}=0.0864\left(\frac{K_{O}^{\prime}}{K_{O}^{\prime}+D O}\right)+0.05 F \cdot M_{D E N} \cdot \eta_{B O D} \cdot\left(\frac{D O}{0.2+D O}\right)
$$

where:

$$
\begin{gathered}
K_{O}{ }_{O}=0.18 \mathrm{mg} \mathrm{L} \mathrm{L}^{-1} ; \eta_{B O D}=0.90-0.95 \text { depending on } F: M_{D E N} \text { in the range } \\
0.4-0.2 \mathrm{kgBOD}_{5} \mathrm{~d}^{-1} \mathrm{kgMLVSS}^{-1} \text {. }
\end{gathered}
$$

\subsection{Limiting DO concentration in denitrification processes}

As mentioned, small levels of DO are constantly present in biological pre-denitrification reactors, inducing adverse effects on the kinetics of nitrogen removal, and consequently on denitrification performance.

Normally, a great part of the oxygen supplied to the anoxic reactor can be attributed to the mixed-liquor recycle, while a small contribution is given by raw sewage, and that of sludge recycle can be considered negligible. In addition, surface dissolution exchanges from the atmosphere should also be considered. As a result, daily average concentrations measured in real scale facilities are mostly in the range $0.2-0.4 \mathrm{mg} \mathrm{L}^{-1}$, with higher peaks during the day, especially in small plants, characterized by strong fluctuations of flow rate and quality (Raboni et al., 2013a).

Minimizing DO in the mixed-liquor recycle stream seems relevant for limiting DO additions to denitrification. Addition of a post-anoxic reactor (after the pre-denitrification and oxidation-nitrification steps) has been proposed (Urbini et al., 2015) as a possible means of increasing denitrification performance.

A further strategy for DO control is based on the addition of reducing agents that can react with it. A recent study evidentiated that the most suitable reagent for this purpose is a salt of ferrous iron $\left(\mathrm{Fe}^{2+}\right)$, that proved to be very efficient in controlling DO while rapidly oxidizing to ferric ion (Viotti et al., 2015). At the same time ferric ion reacts with phosphorous, precipitating as ferric orthophosphate. Tests proved that a dosage of $6 \mathrm{mgFe}^{2+} \mathrm{L}^{-1}$ can lower the mean DO concentration from $0.45 \mathrm{mg} \mathrm{L}^{-1}$ to $0.28 \mathrm{mg} \mathrm{L}^{-1}$, increasing denitrification efficiency from $64.8 \%$ to $77 \%$. This efficiency was progressively increased to $89 \%$ dosing ferrous ion at $9 \mathrm{mg} \mathrm{L}^{-1}$ (50\% over stoichiometric for $\mathrm{P}$ removal), achieving average DO of $0.1 \mathrm{mg} \mathrm{L}^{-1}$. This also confirmed the strong influence of DO on SDNR suggesting that maintaining DO values lower than $0.2 \mathrm{mg} \mathrm{L}^{-1}$ may achieve high denitrification efficiency.

\subsection{Influence of denitrification reactor hydrodynamics}

Pilot plant studies highlighted the influence of hydrodynamics of DEN on denitrification efficiency (Raboni et al., 2015). In particular, Retention Time Distribution (RTD) influences the concentrations of the denitrification reactants $\left(\mathrm{NO}_{3}-\mathrm{N}\right.$ and $\left.\mathrm{BOD}\right)$, but has also an influence on residual DO, and consequently on denitrification efficiency. A denitrification reactor 
composed of 4 reactors in series has an oxygen consumption capacity greater than a single complete mixing reactor (which allows, at equal conditions, a residual DO of $0.18-0.30 \mathrm{mg} \mathrm{L}^{-1}$ ). The study showed a noticeable difference in SDNR values between the two reactor models. In fact, the model with four reactors in series has demonstrated a higher efficiency of $16.6 \%$ (compared to the complete mixing model) at $\mathrm{F}: \mathrm{M}_{\mathrm{DEN}}=0.2 \mathrm{kgBOD}_{5} \mathrm{~d}^{1} \mathrm{kgMLVSS}^{-1}$; this percentage has increased to $25 \%$ at $\mathrm{F}: \mathrm{M}_{\mathrm{DEN}}=0.4 \mathrm{kgBOD}_{5} \mathrm{~d}^{-1} \mathrm{kgMLVSS}^{-1}$. Hence, hydrodynamic configuration plays an important role in the efficiency of the anoxic reactor, conditioning residual DO concentration and, consequently, denitrification performance. For the same reasons, the right selection of the operating $\mathrm{F}: \mathrm{M}$ ratio in denitrification is of great importance.

\subsection{Denitrification efficiency in small treatment plants}

Large variations in quantity and quality of sewage, typical of small communities, make it hard to achieve high biological denitrification efficiencies (i.e. $\eta \geq 90 \%$ ). In a specific study of a pre-denitrification plant, fed by sewage of a community of 15,000 inhabitants, an average efficiency of only $60.2 \%$ was achieved, with isolated peaks of $75 \%$ (Raboni et al., 2013a). Two factors affected this result:

- Great variability of the $\mathrm{BOD}_{5} / \mathrm{NO}_{3}-\mathrm{N}$ ratio in denitrification, implying a shortage of carbon $\left(\mathrm{BOD}_{5}\right)$ for denitrification at different times of the day;

- Accumulation of DO in DEN, in the periods of lower $\mathrm{BOD}_{5}$ inflow at night time and early in the day, reaching peak values of $1.2 \mathrm{mgO}_{2} \mathrm{~L}^{-1}$, enough to determine inhibitory effects on the denitrification rate.

It was shown that, by adding supplemental carbon, it was possible to overcome the difficulties encountered and achieve denitrification efficiencies greater than $90 \%$. A practical solution could likely consist of the introduction of an equalization tank before the treatment. The choice of a simultaneous denitrification process (achieving complete mixing conditions), also appears of interest.

\section{ADVANCES IN DENITRIFICATION PROCESSES AND TECHNOLOGIES}

\subsection{Deammonification}

\subsubsection{Deammonification cycle vs. conventional processes}

Deammonification is a biological treatment process used to convert ammonia to nitrogen gas. It includes both nitritation and the anaerobic ammonia-oxidizing (anammox) processes. Nitritation, aerobic oxidation of ammonia- $\mathrm{N}\left(\mathrm{NH}_{4}-\mathrm{N}\right)$ to nitrite-nitrogen $\left(\mathrm{NO}_{2}-\mathrm{N}\right)$ is carried out by autotrophic, Aerobic Ammonia-Oxidizing Bacteria (AerAOB): a well-known process in wastewater treatment which forms the initial step of biological nitrification of $\mathrm{NH}_{4}-\mathrm{N}$ to nitrates $\left(\mathrm{NO}_{3}-\mathrm{N}\right)$.

The anammox reaction is carried out by Planctomycetales, autotrophic, Anaerobic Ammonia-Oxidizing Bacteria (AnAOB) which use $\mathrm{NO}_{2}-\mathrm{N}$ as electron acceptor to anaerobically oxidize $\mathrm{NH}_{4}-\mathrm{N}$ to $\mathrm{N}_{2}$ (Strous et al., 1999). In the overall process, about $89 \%$ of the inorganic nitrogen $\left(\mathrm{NH}_{4}-\mathrm{N}+\mathrm{NO}_{2}-\mathrm{N}\right)$ ends up as $\mathrm{N}_{2}$ gas and about $11 \%$ as $\mathrm{NO}_{3}-\mathrm{N}$. Deammonification and the complete denitrification reaction are illustrated in Figure 1. 


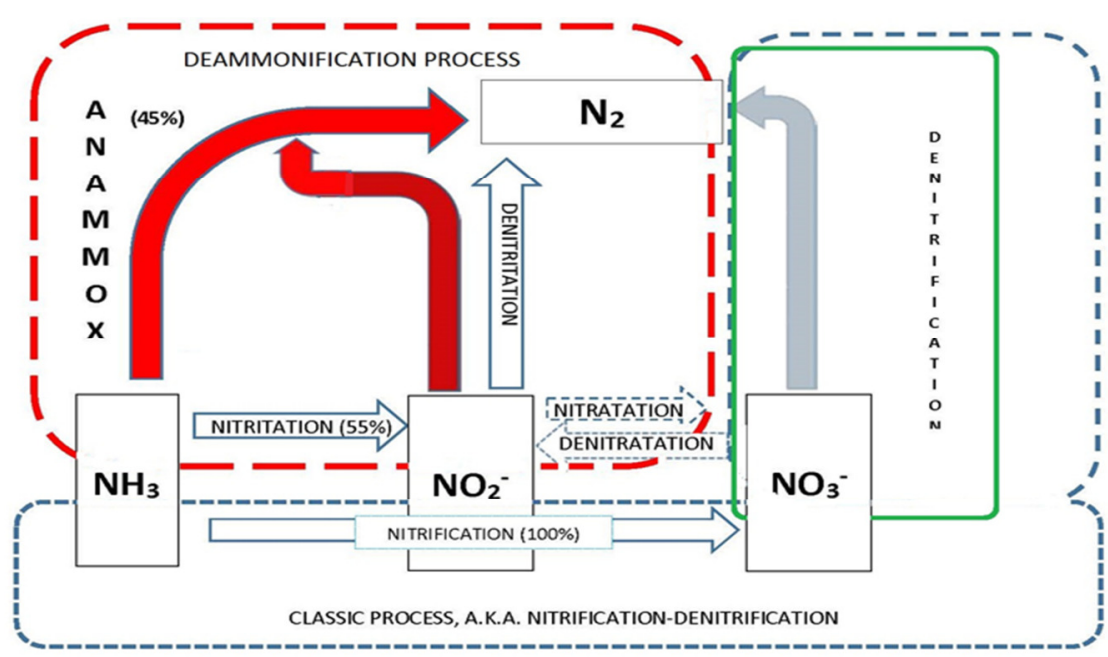

Figure 1. Simplified scheme of the Deammonification and nitrification/denitrification processes.

In order to facilitate the understanding throughout the paper, we introduce Table 1 with the major acronyms and units used in the discussion.

Table 1. Nomenclature of terms and symbols.

\begin{tabular}{lll}
\hline \multicolumn{1}{c}{ Symbol } & \multicolumn{1}{c}{ Unit of measurement } & \multicolumn{1}{c}{ Description } \\
\hline$D O$ & $\mathrm{mgO}_{2} \mathrm{~L}^{-1}$ & Dissolved oxygen concentration \\
$\triangle N O_{3}-N$ & $\mathrm{mgNO}_{3}-\mathrm{N} \mathrm{L}^{-1}$ & Nitrate concentration removed, as $\mathrm{N}$ \\
$\eta$ & - & Fraction of heterotrophic bacteria that use nitrate in \\
$\eta_{B O D}$ & - & lieu of oxygen \\
$K$ & $\mathrm{~h}^{-1}$ & BOD removal efficiency \\
$K_{D}$ & $\mathrm{~h}^{-1}$ & Maximum specific substrate utilization rate \\
$K_{N}$ & $\mathrm{mgNO}_{3}-\mathrm{N} \mathrm{L}^{-1}$ & Endogenous decay coefficient \\
$K_{S}$ & $\mathrm{mg} \mathrm{L}^{-1}$ & Nitrate utilization half-velocity coefficient \\
$K^{\prime}$ & $\mathrm{mgO}_{2} \mathrm{~L}^{-1}$ & Substrate utilization half-velocity coefficient \\
$F: M$ & $\mathrm{gBOD}_{5} \mathrm{~d}^{-1} \mathrm{gMLVSS}^{-1}$ & Oxygen inhibition constant \\
$M L V S S$ & - & Sludge load \\
$N O_{3}-N$ & $\mathrm{mgNO}_{3}-\mathrm{N} \mathrm{L}^{-1}$ & Mixed-Liquor Volatile Suspended Solids \\
$Q$ & $\mathrm{~m}^{3} \mathrm{~d}^{-1}$ & Nitrate concentration, as N \\
$r_{D E N}$ & $\mathrm{gNO}_{3}-\mathrm{N} \mathrm{h}^{-1} \mathrm{kgMLVSS}^{-1}$ & Flow rate \\
$r_{D E N}$, & $\mathrm{gNO}_{3}-\mathrm{N} \mathrm{h}^{-1} \mathrm{kgMLVSS}^{-1}$ & Denitrification rate \\
$S$ & $\mathrm{mg} \mathrm{L}^{-1}$ & Denitrification rate proposed by Tchobanoglous et \\
$S D N R$ & $\mathrm{gNO}_{3}-\mathrm{N} \mathrm{gMLVSS}^{-1} \mathrm{~d}^{-1}$ & al. (2003) \\
$T$ & ${ }^{\circ} \mathrm{C}^{3}$ & Soluble degradable substrate concentration \\
$V_{D E N}$ & $\mathrm{~m}^{3}$ & Specific DeNitrification Rate \\
$\theta$ & - & Temperature \\
$Y$ & $\mathrm{mgVSS} \mathrm{mg}^{-1}$ substrate consumed & Denitrification reactor volume \\
$X$ & $\mathrm{mgMLVSS} \mathrm{L}^{-1}$ & Coefficient of the Arrhenius equation \\
& & Heterotrophic bacteria synthesis yield \\
& & Biomass concentration in the activated sludge \\
\hline $\mathrm{T}$ & ${ }^{\circ} \mathrm{C}^{\circ} \mathrm{Subscripts}$ and superscripts \\
\hline & - & Temperature \\
\hline & & At 20 ${ }^{\circ} \mathrm{C}$ \\
\hline
\end{tabular}

\section{IPABH}


In the conventional denitrification process, $\mathrm{NH}_{4}-\mathrm{N}$ is oxidized first to $\mathrm{NO}_{2}-\mathrm{N}$ and then to $\mathrm{NO}_{3}-\mathrm{N}$ by autotrophic bacteria. The $\mathrm{NO}_{3}-\mathrm{N}$ is then biologically reduced to $\mathrm{N}_{2}$ by heterotrophic bacteria (denitrification) with the consumption of organic substrate in anoxic conditions (blue process path in Figure 1). Aerobic biological nitrification is well known and is accomplished by Nitroso-bacteria (Nitrosomonas) for $\mathrm{NH}_{4}-\mathrm{N}$ oxidation to $\mathrm{NO}_{2}-\mathrm{N}$ and by Nitro-bacteria (Nitrobacter) for $\mathrm{NO}_{2}-\mathrm{N}$ oxidation to $\mathrm{NO}_{3}-\mathrm{N}$.

In the nitritation/denitritation process, $\mathrm{NH}_{4}-\mathrm{N}$ is oxidized to $\mathrm{NO}_{2}-\mathrm{N}$, and then biologically reduced to $\mathrm{N}_{2}$ by heterotrophic bacteria with the consumption of organic substrate in anoxic conditions (red process path in Figure 1). In the deammonification process, aerobic nitritation of $\mathrm{NH}_{4}-\mathrm{N}$ to $\mathrm{NO}_{2}-\mathrm{N}$, accounts for the transformation of about $55 \%$ of the $\mathrm{NH}_{4}-\mathrm{N}$ fed. The remaining $\mathrm{NH}_{4}-\mathrm{N}$ is anaerobically oxidized with $\mathrm{NO}_{2}-\mathrm{N}$ to $\mathrm{N}_{2}$ gas in the anammox process. In practice, the process skips the need for complete $\mathrm{NO}_{2}-\mathrm{NO}_{3}$ oxidation, and subsequent $\mathrm{NO}_{3}$ denitrification to nitrogen gas (green path in Figure 1). Compared to conventional nitrification and denitrification, the aeration and the carbon-source demand is reduced by over $50 \%$ and $100 \%$, respectively. It should be noted that specific biomass production is higher in the conventional process than in the deammonification process ( $20 \mathrm{~g} \mathrm{COD}$ biomass vs. $3 \mathrm{~g} \mathrm{COD}_{\text {biomass }}$ per mole of $\mathrm{NH}_{4}{ }^{+}$degraded).

In the absence of dissolved oxygen, heterotrophic bacteria can oxidize organic substrate with $\mathrm{NO}_{2}-\mathrm{N}$ or $\mathrm{NO}_{3}-\mathrm{N}$ as electron acceptor to reduce oxidized nitrogen to $\mathrm{N}_{2}$ gas. These reactions for $\mathrm{NO}_{2}-\mathrm{N}$ and $\mathrm{NO}_{3}-\mathrm{N}$ reduction are termed denitritation and denitratation, respectively. The stoichiometry of biological denitritation and denitratation reactions with acetate consumption and heterotrophic biomass growth are:

Denitritation (nitrite reduction by heterotrophic bacteria) (Equation 6).

$$
\begin{aligned}
& 1.0 \mathrm{NO}_{2}^{-}+1.0 \mathrm{H}^{+}+0.24 \mathrm{NH}_{4}^{+}+0.975 \mathrm{CH}_{3} \mathrm{COO}^{-} \rightarrow 0.5 \mathrm{~N}_{2}+0.24 \mathrm{C}_{5} \mathrm{H}_{7} \mathrm{O}_{2} \mathrm{~N}+0.015 \\
& \mathrm{CO}_{2}+0.735 \mathrm{HCO}_{3}^{-}+1.235 \mathrm{H}_{2} \mathrm{O}
\end{aligned}
$$

Denitratation (nitrate reduction by heterotrophic bacteria) (Equation 7).

$$
\begin{aligned}
& 1.0 \mathrm{NO}_{3}^{-}+1.0 \mathrm{H}^{+}+0.33 \mathrm{NH}_{4}^{+}+1.45 \mathrm{CH}_{3} \mathrm{COO}^{-} \rightarrow 0.5 \mathrm{~N}_{2}+0.33 \mathrm{C}_{5} \mathrm{H}_{7} \mathrm{O}_{2} \mathrm{~N}+0.13 \mathrm{CO}_{2} \\
& +1.12 \mathrm{HCO}_{3}^{-}+1.62 \mathrm{H}_{2} \mathrm{O}
\end{aligned}
$$

Therefore, $6.6 \mathrm{~g}$ of acetate $\mathrm{COD}$ are needed per $\mathrm{g}$ of $\mathrm{NO}_{3}-\mathrm{N}$ denitrified (Equation 7). For denitritation of $\mathrm{NO}_{2}-\mathrm{N}$, about $30 \%$ less is needed, at $4.5 \mathrm{~g}$ acetate COD per $\mathrm{g}$ of $\mathrm{NO}_{2}-\mathrm{N}$ denitrified (Equation 6).

Anammox involves the exoenergetic reaction of $\mathrm{NH}_{4}-\mathrm{N}$ oxidation by $\mathrm{NO}_{2}-\mathrm{N}$, and uptake of $\mathrm{CO}_{2}$ and nutrients by autotrophic anammox bacteria for biomass growth. The overall reaction, accounting for cell synthesis, was described in Equation 8 by Strous et al. (1998).

$$
\begin{aligned}
& 1.0 \mathrm{NH}_{4}^{+}+1.32 \mathrm{NO}_{2}^{-}+0.066 \mathrm{HCO}_{3}^{-}+0.13 \mathrm{H}^{+} \rightarrow 1.02 \mathrm{~N}_{2}+0.26 \mathrm{NO}_{3}^{-}+0.066 \\
& \mathrm{CH}_{2} \mathrm{O}_{0.5} \mathrm{~N}_{0.15}+2.03 \mathrm{H}_{2} \mathrm{O}
\end{aligned}
$$

During anaerobic oxidation of ammonia (Equation 8), some nitrates are formed from nitrites, which may provide reducing power for fixation of carbon dioxide (Schmidt et al., 2002). Eq. (8) also indicates that removal of 1.0 mole of $\mathrm{NH}_{4}-\mathrm{N}$ requires 1.32 moles of $\mathrm{NO}_{2}-\mathrm{N}$ and produces 0.26 moles of $\mathrm{NO}_{3}-\mathrm{N}$. Combination of nitritation and deammonification reactions gives the overall deammonification reaction (Equation 9).

$$
\begin{aligned}
& 1.0 \mathrm{NH}_{4}{ }^{+}+0.804 \mathrm{O}_{2}+0.071 \mathrm{HCO}_{3}{ }^{-} \rightarrow 0.436 \mathrm{~N}_{2}+0.111 \mathrm{NO}_{3}{ }^{-}+0.009 \mathrm{C}_{5} \mathrm{H}_{7} \mathrm{O}_{2} \mathrm{~N}+0.028 \\
& \mathrm{CH}_{2} \mathrm{O}_{0.5} \mathrm{~N}_{0.15}+1.038 \mathrm{H}^{+}+1.46 \mathrm{H}_{2} \mathrm{O}
\end{aligned}
$$


The stoichiometric ratio of nitrate production to ammonium consumption for the anammox bacteria is 1:0.382. In real applications, deammonification has demonstrated ammonia reductions of $90-95 \%$ and total nitrogen reductions of $80-85 \%$ (WERF, 2014).

Table 2 summarizes the benefits of the deammonification process in comparison to the conventional denitrification process.

Table 2. Comparison between deammonification process and conventional denitrification process (WERF, 2014).

\begin{tabular}{|c|c|c|c|}
\hline Parameter & Deammonification & $\begin{array}{c}\text { Nitritation/Denitritation } \\
(\eta=89 \%)\end{array}$ & $\begin{array}{l}\text { Nitrification/Denitrification } \\
\qquad(\eta=89 \%)\end{array}$ \\
\hline $\mathrm{O}_{2}$ demand & $\begin{array}{l}1.84 \mathrm{gO}_{2} \mathrm{gNH}_{4}-\mathrm{N}^{-1} \\
\text { removed }\end{array}$ & $\begin{array}{l}2.65 \mathrm{gO}_{2} \mathrm{gNH}_{4}-\mathrm{N}^{-1} \\
\text { removed }\end{array}$ & $\begin{array}{c}3.3 \mathrm{gO}_{2} \mathrm{gNH}_{4}-\mathrm{N}^{-1} \\
\text { removed }\end{array}$ \\
\hline $\begin{array}{l}\text { Acetate-COD } \\
\text { demand }\end{array}$ & 0 & $\begin{array}{c}4.5 \mathrm{~g}_{\text {acetate }} \mathrm{COD} \mathrm{gNO}_{2-} \\
\mathrm{N}^{-1} \text { removed }\end{array}$ & $\begin{array}{c}6.6 \mathrm{~g} \text { acetate } \mathrm{COD} \mathrm{gNO}_{3^{-}} \\
\mathrm{N}^{-1} \text { removed }\end{array}$ \\
\hline $\begin{array}{l}\text { Biomass } \\
\text { production }\end{array}$ & $\begin{array}{l}0.12 \underset{1}{\mathrm{gVSS} g \mathrm{gNH}_{4}-\mathrm{N}^{-}} \\
\text {removed }\end{array}$ & $\begin{array}{l}1.5 \mathrm{gVSS} \mathrm{gNH}_{4}-\mathrm{N}^{-1} \\
\text { removed }\end{array}$ & $\begin{array}{l}1.93 \mathrm{gVSS} \mathrm{gNH}_{4}-\mathrm{N}^{-1} \\
\text { removed }\end{array}$ \\
\hline
\end{tabular}

\subsubsection{Deammonification technologies}

Several technical solutions have been developed for the deammonification process. Table 3 shows the reported number of installations (as of 2014's end) under various technical proprietary solutions commercially available. These differ in terms of the method to grow and retain anammox bacteria, number of stages, configuration, control strategies, and include granular sludge blanket reactors (GSBRs), suspended growth sequencing batch reactors (SBRs), moving bed biofilm reactors (MBBRs), and rotating biological contactors (RBCs).

The first full-scale facility was built in 2001, and their number has rapidly increased since 2007, operating on side stream dewatering flows and some industrial applications. The DEMON $^{\circledR}$ process has the most installations. The largest facilities are two $12,000 \mathrm{kgN} \mathrm{d}^{-1}$ ANAMMOX $^{\circledR}$ plants in China. A larger $13,500 \mathrm{kgN} \mathrm{d}^{-1}$ DEMON $^{\circledR}$ installation is under construction in the USA (WERF, 2014).

Table 3. Active deammonification facilities worldwide.

\begin{tabular}{|c|c|c|c|c|}
\hline \multirow{2}{*}{$\begin{array}{l}\text { Technology } \\
\text { Trade Name }\end{array}$} & \multirow{2}{*}{ Number* } & \multicolumn{2}{|c|}{ Size $\left[\mathrm{kgN} \mathrm{d}^{-1}\right]$} & \multirow{2}{*}{$\begin{array}{c}\text { First installation } \\
\text { (year) }\end{array}$} \\
\hline & & Smallest & Largest & \\
\hline ANAMMOX $^{\circledR}$ & 22 & 50 & 12,100 & 2002 \\
\hline ANITA $^{\mathrm{TM} M o x}$ & 6 & 110 & 350 & 2010 \\
\hline $\operatorname{DeAmmon}^{\circledR}$ & 3 & 130 & 2,455 & 2001 \\
\hline DEMON $^{\circledR}$ & 37 & 50 & 13,500 & 2004 \\
\hline Terra-N ${ }^{\circledR}$ & 5 & 90 & 750 & 2008 \\
\hline
\end{tabular}

*In operation or construction as of Oct. 2014 (WERF, 2014).

\subsubsection{ANAMMOX ${ }^{\circledR}$ Granulated Sludge Blanket Reactor (GSBR)}

Anammox bacteria can grow in granules readily settling by gravity. GSBRs take advantage of this by employing a high rate clarifier that captures and retains anammox granules, while flushing out competing bacterial flocs. Two arrangements are used: two-step and single-step. 


\section{Two-Step ANAMMOX ${ }^{\circledR}$ Process:}

Developed by the Paques company, it uses the SHARON process (Single reactor system for High Activity Ammonium Removal Over Nitrite), a stable, partial nitrification to nitrite instead of nitrate (Hellinga et al., 1998), to convert ammonia to nitrite, followed by the anammox process (Figure $2 \mathrm{~A}$ ).
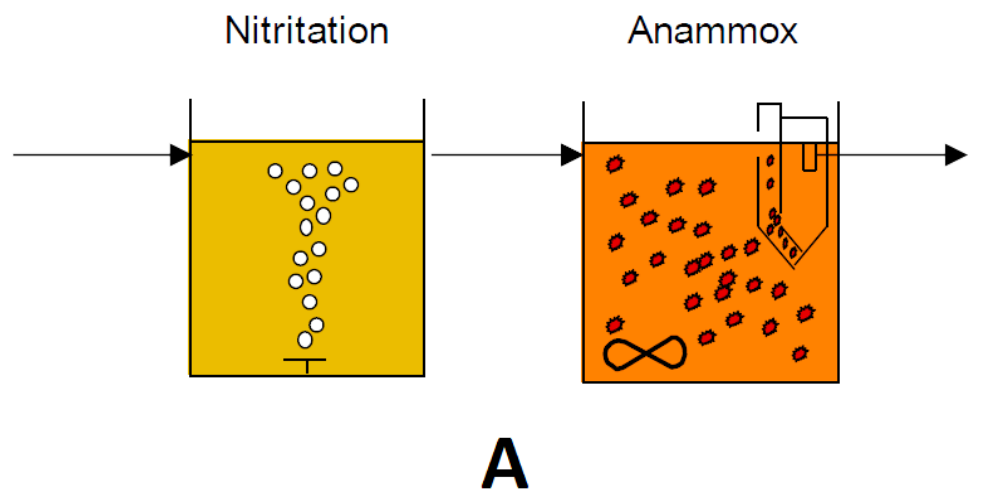

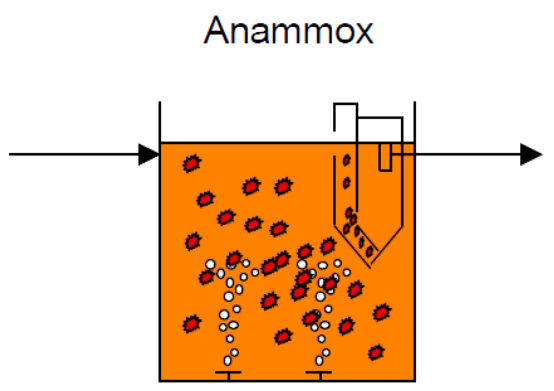

B

Figure 2. Two-step (A) and Single-step (B) anammox process.

This is optimized by controlling $\mathrm{pH}, \mathrm{DO}$, and by taking advantage of the higher growth rate of ammonia-oxidizing bacteria at higher temperatures (Van Loosdrecht and Jetten, 1998). Granular anammox bacteria are retained in the second reactor using up flow clarification. Their conversion capacity is high, up to $4.8 \mathrm{kgTN} \mathrm{m}^{-3} \mathrm{~d}^{-1}$. This system was introduced in the Netherlands at several treatment plants, achieving $80 \%$ ammonia conversion to nitrogen gas at loading rate of $1.2 \mathrm{kgN} \mathrm{m}^{-3} \mathrm{~d}^{-1}$ (van Dongen et al., 2001). A system receiving 1,000-1,300 $\mathrm{mgNH}_{4}-\mathrm{N} \mathrm{L}^{-1}$ could produce an effluent with 5-10 $\mathrm{mg} \mathrm{NO}_{2}-\mathrm{N} \mathrm{L}^{-1}, 60-130 \mathrm{mg}$ $\mathrm{NH}_{4}-\mathrm{N} \mathrm{L}^{-1}$, and about $130 \mathrm{mg} \mathrm{NO}_{3}-\mathrm{N} \mathrm{L}^{-1}$ (Abma et al., 2007).

The advantage of this arrangement is that the two main reactions (nitritation and deammonification) occur in separate reactors, allowing better control of each process. Its disadvantage is that reactor volumes are significantly larger due to the large nitritation reactor needed.

\section{Single-Step ANAMMOX ${ }^{\circledR}$ Process:}

In this process, nitritation and deammonification (anammox) occur in the same reactor (Figure 2B), making process control ( $\mathrm{pH}, \mathrm{DO}$, and Oxidation-Reduction Potential - ORP) essential to prevent bacterial competition for nitrite (heterotrophic denitritation, and in particular autotrophic Nitrite Oxidizing Bacteria - NOBs), while maintaining a long solid retention time (SRT) for anammox bacteria. Ammonia reduction of $95 \%$, with over $80 \%$ total nitrogen reduction, have been reported (Abma et al., 2010).

The advantage of this process is that single reactors are very compact due to high-granule concentration. Granular sludge growth protects the process against high nitrite levels. A disadvantage consists of requiring online control to achieve stable nitritation and deammonification in one reactor. Operational experience with this system has been quite positive in reported cases; therefore, single step ANAMMOX ${ }^{\circledR}$ is the most commonly used.

\section{Incorporation of Anammox in mainstream processes}

Incorporating anammox in mainstream processes is still an emerging technology. Figure 3 illustrates a possible process flowsheet including anammox return sludge treatment in a conventional WWTP (Wett et al., 2010). 


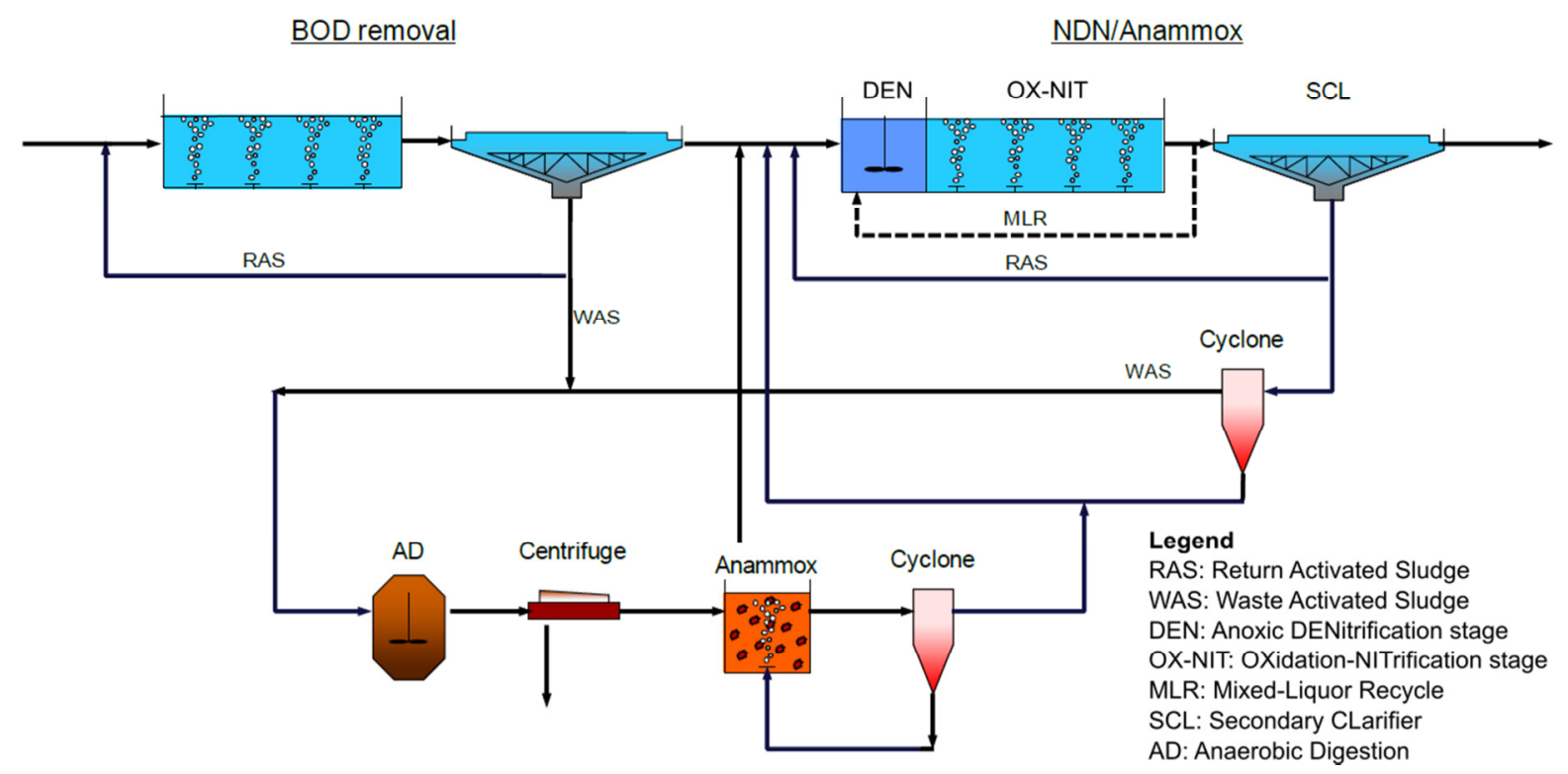

Figure 3. Integration of Anammox process in conventional processes (Wett et al., 2010).

\subsubsection{DEMON ${ }^{\circledR}$ Sequencing Batch Reactor (SBR)}

The DEMON $^{\circledR}$ process (DE-amMONnification) employs aerobic nitrification to nitrite and anaerobic ammonia oxidation under controlled DO and $\mathrm{pH}$ conditions (Wett et al., 2010). The process uses a hydrocyclone to separate heavier granular anammox bacteria from floc-forming bacteria, allowing accumulation of NOBs, and performance stabilization.

Process control addresses three parameters: (1) time of filling and drawing the SBR (feed rate), (2) DO, and (3) $\mathrm{pH}$, to balance the nitritation and anammox reactions (O'Shaughnessy et al., 2008). DO is set to a low value (around $0.3 \mathrm{mg} \mathrm{L}^{-1}$ ) to prevent rapid nitrite production by $\mathrm{AOB}$, and repress NOBs. Aeration cycles control also regulates $\mathrm{pH}$ : nitritation depresses the $\mathrm{pH}$ during aeration, while the anammox reaction increases $\mathrm{pH}$ in its absence. Aeration is initiated at the upper $\mathrm{pH}$ and stopped at the lower $\mathrm{pH}$ set points to maintain $\mathrm{pH}$ within 0.01 units (Wett et al., 2010). The nitritation step may suffer inhibition, leading to process instability.

\subsubsection{Moving-Bed Biofilm Reactor (MBBR)}

MBBR configurations using different types of support media are used for deammonification of high-strength, ammonium-rich recycle streams (Seyfried et al., 2001). AOB and anammox bacteria are established within the biofilm (Figure 4). The main

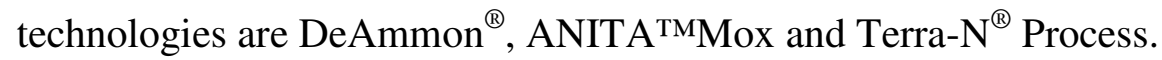

\section{DeAmmon ${ }^{\circledR}$}

Developed by Purac/Läckeby AB (Sweden) in collaboration with the University of Hannover and Ruhrverband (the Ruhr River Association), consists of a single- or dual-train system with three stages per reactor, normally operated in series, with built-in flexibility to allow also parallel operation. For biofilm growth support, Kaldnes K1 filter media (AnoxKaldnes/Veolia) with active area of $500 \mathrm{~m}^{2} \mathrm{~m}^{-3}$ is typically added to fill up to $40 \%$ of the reactor volume. To retain media within each stage, separating screens are placed between stages. Internal recirculation from the third to the first stage may be required for very high-strength streams, to limit ammonia concentration in the first stage. Intermittent aeration supporting partial nitritation and anammox reactions is provided by coarse bubble diffusers. Alternance of aeration/anoxic periods limits nitrite accumulation and restrict the growth of aerobic nitrite-oxidizing bacteria (Plaza et al., 2011; Thöle, 2007). DO concentration of 
$3 \mathrm{mg} \mathrm{L}^{-1}$ during aeration is considered appropriate for design and operation, but higher concentrations are avoided to prevent potential for NOB growth, and limit anammox inhibition. Mechanical mixers ensure well mixed conditions during non-aerated periods. Reactor $\mathrm{pH}$ is usually in the 7.3-7.7 range and not controlled. On-line conductivity measurements are a low-cost tool for performance monitoring and control (e.g. duration of aeration cycles).

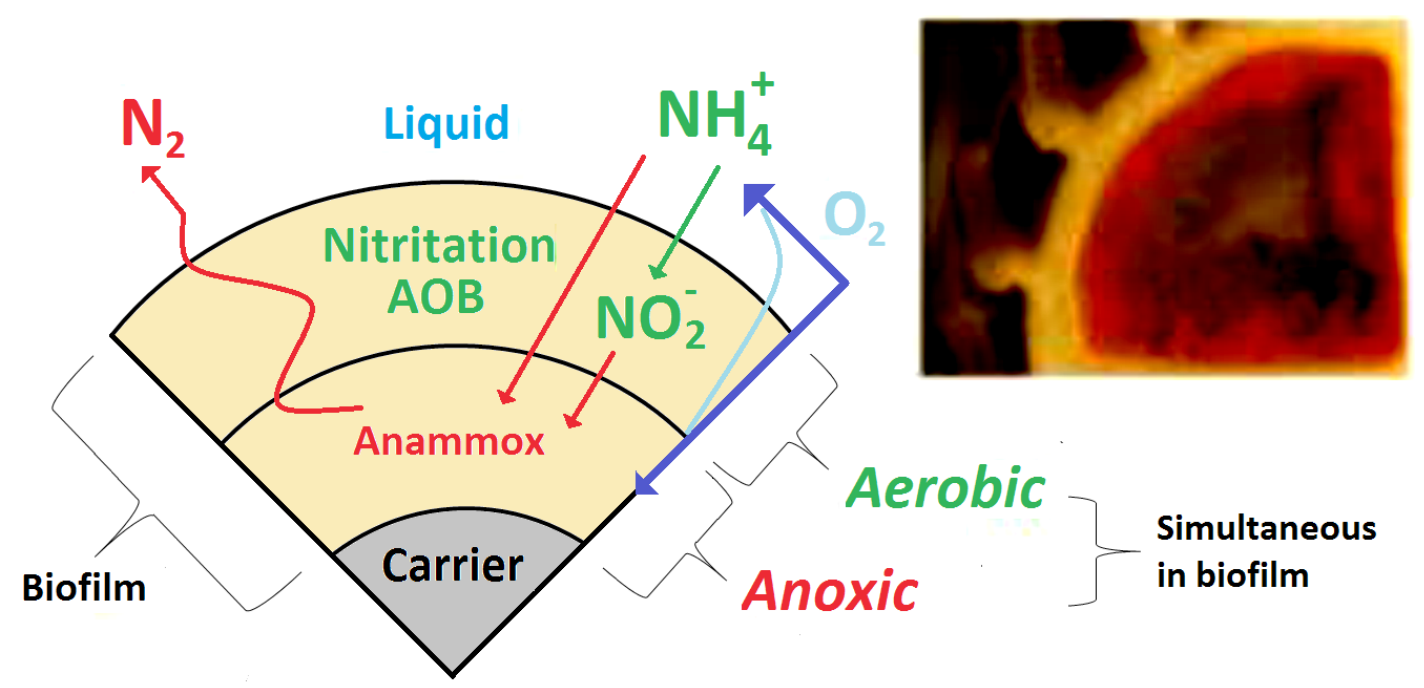

Figure 4. Anammox bacteria in biofilm (Source: Seyfried et al., 2001).

Inorganic nitrogen removal efficiency is usually in the range $70-85 \%$ and in the temperature range $25-30^{\circ} \mathrm{C}$ (Plaza et al., 2011). Minimum process operating temperature is $20^{\circ} \mathrm{C}$, after which substantial performance deterioration occurs (Thöle, 2007). With Kaldnes $\mathrm{K} 1$ media, a design load of $0.6 \mathrm{~kg}-\mathrm{N} \mathrm{m}^{-3} \mathrm{~d}^{-1}$ can be assumed.

\section{ANITA ${ }^{\mathrm{TM}}$ Mox}

ANITA $^{\text {TMMOX }}$ is a single-stage deammonification MBBR system developed by AnoxKaldnes/Veolia. It uses BiofilmChip ${ }^{\mathrm{TM}} M$, a support medium with high specific surface area which allows achieving a volumetric ammonium-N removal rate of up to $1.2 \mathrm{~kg}-\mathrm{N} \mathrm{m}^{-3} \mathrm{~d}^{-1}$ with $40 \%$ media-filled volume in a temperature range of $27-30^{\circ} \mathrm{C}$ (Christensson et al., 2011). The specific ammonium removal rate is approximately $3 \mathrm{~g}-\mathrm{N} \mathrm{m}^{-2} \mathrm{~d}^{-1}$, with ammonium-N and total inorganic nitrogen removal efficiencies of approximately $90 \%$ and $80 \%$, respectively, at $\mathrm{pH}$ in the range 6.7-7.5. The MBBR is continuously aerated with DO concentration controlled in the range $0.5-1.5 \mathrm{mg} \mathrm{L}^{-1}$. The reported energy consumption for the single-stage MBBR is 1.6-1.9 $\mathrm{kWh} \mathrm{kgN}^{-1}$ removed (Christensson et al., 2011).

\section{Terra- $N^{\circledR}$ Process}

Terra- $\mathrm{N}^{\circledR}$ Process, developed by Clariant/SÜD-Chemie AG (Munich, Germany), uses bentonite instead of plastic as support medium for biofilm growth. The process is designed as single-stage SBR, or as two-stages in series, with gravity clarification. The bentonite product contains a wide range of particle sizes, with mean $25-45 \mu \mathrm{m}$, and mean surface area of $60 \mathrm{~m}^{2} \mathrm{~g}^{-1}$, with lower active surface area for biofilm growth.

Bentonite is added at 10-12 $\mathrm{g} \mathrm{L}^{-1}$ to the nitritation stage of the two-stage process, or in the single-stage SBR, resulting in a TSS concentration of $15-20 \mathrm{~g} \mathrm{~L}^{-1}$, at full loading. Granulation of anammox bacteria in the second stage of the two-stage system eliminates the need for a support media in that stage. Second-stage biomass concentrations of $5-7 \mathrm{~g} \mathrm{~L}^{-1}$ have been reported. 
The bentonite induces a high solids settling rate, and compact settled solids, resulting in insignificant losses of bentonite in the effluent. Biomass lost with the effluent by washout is sufficient to control the reactor solids concentration, so no additional solids wastage is normally necessary.

In SBR systems, aeration is intermittent and the aerobic/anoxic pattern is adjusted based on ammonium loading and reactor performance. Mechanical mixing is required to maintain solids in suspension during the SBR anoxic phases, and in the anammox stage of a two-stage system.

Many Terra- $\mathrm{N}^{\circledR}$ systems are retrofits of existing tanks, and operate at loading rates from 0.4 to $1.0 \mathrm{~kg}-\mathrm{N} \mathrm{m}^{-3} \mathrm{~d}^{-1}$ (WERF, 2014); however, with the SBR variant, higher loading rates up to $1.5 \mathrm{~kg}_{-} \mathrm{N} \mathrm{m}^{-3} \mathrm{~d}^{-1}$ are possible. Inorganic nitrogen removal efficiencies are reported in the range $80-90 \%$. Startup time for the SBR or the anammox stage (two-stage process) can be reduced to $60-90 \mathrm{~d}$ by seeding the reactors with anammox-enriched sludge from existing full-scale systems.

\subsubsection{Benefits of deammonification}

The benefits of deammonification can be summarized as:

- Energy savings: aeration energy needed for the process is about $55-60 \%$ of that needed for a conventional nitrification/denitrification process;

- No extra carbon is needed for nitrogen removal. Even if carbon is added to remove the nitrates produced from anammox, total carbon demand is still about $90 \%$ less than that used in the conventional nitrification/denitrification process;

- Greenhouse effects: the process is a net consumer of $\mathrm{CO}_{2}$, compared to that released by heterotrophic bacteria in the conventional nitro/denitro process;

- Alkalinity demand for nitrogen removal is reduced by about $45 \%$;

- The process sludge production is much less than in a conventional nitrification/denitrification plant.

\subsection{Technologies for conventional denitrification with attached biological culture}

\subsubsection{Denitrification in submerged bio filters}

Denitrifying filters have been utilized for wastewater treatment for a number of years. The combination of denitrification and solids removal was first patented in the 1970s. Since then, several companies have developed their own denitrifying filters. There are two main configurations for denitrification filters commercially available: down flow and up flow continuous backwash filters. Down flow denitrification filters operate in a conventional filtration mode and consist of media and support gravel laying on an underdrain. Manufacturers include Severn Trent Services (TETRA Denite ${ }^{\circledR}$ ), F.B. Leopold Co. Inc. (elimi.NITE ${ }^{\circledR}$ ), and Siemens Water Technology (Davco®). In up flow continuous-backwash filters, wastewater flows upward through the filter, countercurrent to the movement of the sand bed. Manufacturers include Parkson Corp. (DynaSand ${ }^{\circledR}$ ), and Paques bv. (Astrasand ${ }^{\circledR}$ ) (US-EPA 2007). Other configurations include Biologically Active Filter (BAF) with floating media, continuous backwashing moving bed filters, and nonbackwashing, and submerged filters. BAF with floating media includes systems with polystyrene, polypropylene, or polyethylene media, such as Kruger Biostyr ${ }^{\circledR}$. These are backwashed using intermittent countercurrent flow, and are typically designed to also remove suspended solids to secondary levels. Continuous backwashing moving bed filters operate in up flow mode and consist of media heavier than water continuously moving countercurrent to the wastewater. Media is directed to a central air lift where it is scoured, rinsed, and returned to the top of the media bed. Well-known filters are DynaSand ${ }^{\circledR}$, AstraSand ${ }^{\circledR}$, and Centraflo ${ }^{\circledR}$, typically designed to 
produce filter-quality effluent $(<5 \mathrm{NTU})$. Nonbackwashing, submerged filters consist of submerged, static media and are often referred to as submerged aerated filters (SAF), although recent work applied this technology in anoxic conditions for denitrification. Solids are carried through the reactor and removed by a separate, dedicated solid-separation process (WERF, 2010).

Leopold elimi-NITE $^{\circledR} 2.0$ denitrification system reduces nitrate-nitrogen in wastewater effluent by converting it to nitrogen gas. The biological conversion is done in an attached growth, down flow, deep bed, mono-media filter. Oxygen is removed to create an anoxic environment for denitrification, and particulate matter as well as insoluble $\mathrm{P}$ is removed. The system adds a supplemental carbon source or microbiological food needed to metabolize nitrogen (Leopold, 2003).

BIOSTYR ${ }^{\circledR}$ is a process based on the biological filter principle to fix biomass in a biofilm combination. The bed is formed by special polystyrene balls with a diameter of $4.5 \mathrm{~mm}$, kept inside the filter thanks to the filter-jets ceiling. Biomass development starts in the filter-bed, while removing nitrogen from sewage water. Periodical cleaning of the filter is made by purified wastewater stored over the filter ceiling. Dosing of an external substrate (methanol) is necessary for nitrate-nitrogen denitrification. Installation of a separation stage is not necessary, and the fixed biomass enables rather high volumetric loading. This technology is used for post denitrification, when a low concentration of $\mathrm{TN}$ is achieved and specific consumption of external substrate can be minimized.

Airlift reactors with biofilm attached on fixed supports exploit the different DO concentrations within the biofilm for nitrogen removal. In such systems, a Simultaneous Nitrification and Denitrification (SND) process occurs in the outer and inner part of the biofilm, respectively. The advantages of these reactors are the small volumes, a low-odor sludge due to high DO concentration, and low suspended solids content in the effluent (Luciano et al., 2012; Viotti et al., 2014).

\subsubsection{Moving bed biofilm and fluidized bed biofilm reactors}

A moving bed biofilm reactor (MBBR) is a process utilizing a basin filled with a carrier medium that promotes attachment and growth of biofilm carrying out biological treatment. MBBRs have been extensively used for BOD/COD removal, as well as for nitrification and denitrification in municipal and industrial wastewater treatment. Nitrification rates as high as $1.2 \mathrm{gNH}_{4}-\mathrm{N} \mathrm{m}^{-2} \mathrm{~d}$ were demonstrated in practical operation at low temperatures $\left(11^{\circ} \mathrm{C}\right)$, while denitrification rates as high as $3.5 \mathrm{gNO}_{3}-\mathrm{N}_{\text {equiv. }} \mathrm{m}^{-2} \mathrm{~d}^{-1}$ have been reported. Depending on pretreatment needs, total hydraulic retention time (HRT) of a MBBR for N-removal will be in the range of 3-5 h (Ødegaard, 2006).

The carrier media is either in fixed form as sheets/rope or made by buoyant, loose plastic media requiring energy in the form of either aeration or mixing for buoyancy, showing at the same time durability by not so far requiring replacement as in first generation MBBRs built over 15 years ago (Rusten et al., 1996). The primary difference between BAFs and MBBRs is that an MBBR does not provide any filtration or require any backwash. Rather, a separation process downstream of the unit removes solids from the stream. Downstream separation technologies used include sedimentation, flotation, filtration, high-rate clarifiers, and membranes (WERF, 2010).

Fluidized Bed Biofilm Reactor (FBBR) is a treatment process that utilizes carrier media to promote attached growth like BAFs and MBBRs; similarly to MBBRs, FBBRs do not filter solids and require downstream solids separation. Carrier media selection governs process sizing: historically, carrier medium of choice has been either silica sand or granular activated carbon (GAC). (Coahelso et al., 1992). A FBBR operates in up flow mode with the media fluidized within the reactor as the drag force associated with the feed up flow exceeds the 
gravity force pulling down particles, and lifts the carrier media. This configuration (i) maximizes media exposure between attached biomass and the feed stream, (ii) avoids plugging, and (iii) provides scour to maintain a thin biofilm improving mass transfer. Despite small footprints, FBBRs suffer from scale-up issues and lack of commercial systems (Sutton and Mishra, 1994).

\subsubsection{Membrane Biofilm Reactors (MBfR)}

MBfR is an emerging technology for water and wastewater treatment, based on pressurized membranes that supply a gaseous substrate to a biofilm formed on the membrane's exterior. MBfR biofilms behave differently from conventional biofilms due to their counter-diffusion of substrates, and are suited for numerous treatment applications, including removal of carbon and nitrogen when oxygen is supplied, and reduction of oxidized contaminants (such as nitrate) when hydrogen is supplied. Major benefits include high gas utilization efficiency, low energy consumption, and small reactor footprints. MBfRs development still faces challenges, including biofilm management, design of scalable reactor configurations, and identification of cost-effective membranes (Martin and Nerenberg, 2012).

\section{CONCLUSIONS}

The paper presents some of the most recent advances in biological nitrogen removal. Both design criteria of conventional denitrification processes and technological innovations have been considered.

With reference to former, a new equation for SDNR applicable to reactor sizing was proposed, highlighting the influence of both Dissolved Oxygen (DO) and the F:M ratio in the denitrification reactor on process design. The adverse effect of DO in a conventional denitrification anoxic reactor is quite relevant, and its minimization, mainly by reduction in the mixed-liquor recycle, or by addition of a post-anoxic reactor (after pre-denitrification and oxidation-nitrification) should be pursued. An alternative for controlling DO in the denitrification phase is based on the addition of chemical reducing agents that can react with DO. Specifically, the most suitable reagent has proved to be a salt of ferrous iron, evidencing that such dosages can be very efficient in controlling DO, as it rapidly oxidizes ferrous to ferric ion, subsequently reacting with phosphorous and precipitating as orthophosphate.

Of great importance are also recent studies highlighting the limits of denitrification efficiency in small community plants, due to the strong load fluctuations. Effects of the hydrodynamic behavior of the denitrification reactor (complete-mixing or plug-flow) on the denitrification performance have been proven equally important.

The greatest technological innovation to date regards the increasing diffusion of "deammonification" processes, often better known by their patent names (ANAMMOX ${ }^{\circledR}$, DEMON $^{\circledR}$, CANON $^{\circledR}$, ANITA $^{\circledR}$ and others). Deammonification is achieved by bacteria capable of using nitrous ions as electron acceptors to degrade ammonia to nitrogen. The process reduces aeration and carbon-source demands by over $50 \%$ and $100 \%$, respectively, compared with traditional nitrification-denitrification and has already found industrial applications in the treatment of high-strength wastewater such as digested sludge liquor and landfill leachate.

A promising new technology MBfRs is based on pressurized membranes supplying a gaseous substrate to a biofilm formed on the membrane's exterior. These can be used in both oxidizing (COD removal) and reducing (nitrate removal) processes depending on the substrate provided. 


\section{ACKNOWLEDGEMENT}

Part of the work that led to this paper has been performed under the project No. LO1408 "AdMaS UP - Advanced Materials, Structures and Technologies" supported by the Czech Ministry of Education, Youth and Sports under the "National Sustainability Programme I".

\section{REFERENCES}

ABMA, W. R.; SCHULTZ, C. E.; MULDER, J. W.; VAN DER STAR, W. R. L.; STROUS, M.; TOKUTOMI, T. et al. Full-scale granular sludge Anammox process. Water Science and Technology, v. 55, n. 8-9, p. 27-33, 2007.

http://dx.doi.org/10.2166/wst.2007.238

ABMA, W. R.; DRIESSEN, W.; HAARHUIS, R.; VAN LOOSDRECHT, M. C. M. Upgrading of sewage treatment plant by sustainable and cost-effective separate treatment of industrial wastewater. Water Science and Technology, v. 61 n. 7, p. 17151722, 2010. http://dx.doi.org/10.2166/wst.2010.977

CHRISTENSSON, M.; EKSTRÖM, S.; LEMAIRE, R.; LE VAILLANT, E.; BUNDGGAARD, E.; CHAUZY, J. et al. ANITA ${ }^{\mathrm{TM} M o x}$ - A Biofarm Solution for Fast Start-Up of Deammonifying MBBRs. In: WATER ENVIRONMENT FEDERATION, 84., 15-19 October 2011, Los Angeles, CA. Proceedings.... Sacramento: ACWA, 2011.

CAPODAGliO, G. A.; HLAVÍNEK, P.; RABONI, M. Physico-chemical technologies for nitrogen removal from wastewaters: a review. Revista Ambiente \& Agua, v. 10, n. 3, p. 481-498, 2015. http://dx.doi.org/10.4136/ambi-agua.1618

COAHELSO, I.; BOAVENTURA, R.; RODRIGUES, A. Biofilm reactors - An experimental and modeling study of wastewater denitrification in fluidized-bed reactors of activated carbon particles. Biotechnology and Bioengineering., v. 40, n. 5, p. 625-633, 1992. http://dx.doi.org/10.1002/bit.260400510

EKAMA, G.A. Biological Nutrient Removal. In: Reference Module in Earth Systems and Environmental Sciences - Volume 4: Treatise on Water Science. Amsterdam: Elsevier, 2011. p. 409-526. doi: http://dx.doi.org/10.1016/B978-0-444-53199-5.00094-4

HELliNGA, C.; SCHELlEN, A. A. J. C.; MULDER, J. W.; VAN LOOSDRECHT, M. C. M.; HEIJNEN, J. J. The SHARON process: an innovative method for nitrogen removal from ammonium-rich waste water. Water Science and Technol., v. 37, n. 9, p. 135142, 1998. http://dx.doi.org/10.1016/S0273-1223(98)00281-9

LEOPOLD COMPANY, INC. Leopold elimi-NITE Denitrification System. 2003. Available in: http://www.xylemwatersolutions.com. Access in: September 2015.

LUCIANO, A.; VIOTTI, P.; MANCINI, G.; TORRETTA, V. An integrated wastewater treatment system using a BAS reactor with biomass attached to tubular supports. Journal of Environmental Management, v. 113, p. 51-60, 2012.

MARTIN, K. J.; NERENBERG, R. The membrane biofilm reactor (MBfR) for water and wastewater treatment: principles, applications, and recent developments. Bioresource Technology, v. 122, p. 83-94, 2012. http://dx.doi.org/10.1016/j.biortech.2012.02.110 
ØDEGAARD, H. Innovations in wastewater treatment: the moving bed biofilm process. Water Science and Technology, v. 53, n. 9, p. 17-33, 2006.

http://dx.doi.org/10.2166/wst.2006.284

OH, J.; SILVERSTEIN, J. Oxygen inhibition of activated sludge denitrification. Water Research, v. 33, n. 8, p. 1925-1937, 1999. http://dx.doi.org/10.1016/S00431354(98)00365-0

O'SHAUGHNESSY, M.; SIZEMORE, J.; MUSABYIMANA, M.; SANJINES, P.; MURTHY, S.; WETT, B. et al. Operations and process control of the deammonification (DEMON) process as a sidestream option for nutrient removal. In: WATER ENVIRONMENT FEDERATION, WEFTEC 2008, 18-22 Oct., Chicago. Proceedings... Chicago: WEF, 2008. p. 6333-6348.

http://dx.doi.org/10.2175/193864708788809743

PLAZA, E.; STRIDH, S.; ÖRNMARK, J.; KANDERS, L.; TRELA, J. Swedish experience of the deammonification process in a biofilm system. In: WATER ENVIRONMENT FEDERATION, NUTRIENT RECOVERY AND MANAGEMENT, 9-12 Jan. 2011, Miami. Proceedings... Miami: WEF, 2011. p. 1067-1079.

http://dx.doi.org/10.2175/193864711802867397

PLÓSZ, B. G.; JOBBÁGY, A.; LESLIE GRADY JR., C. P. Factors influencing deterioration of denitrification by oxygen entering an anoxic reactor through the surface. Water Research, v. 37, n. 4, p. 853-863, 2003. http://dx.doi.org/10.1016/S00431354(02)00445-1

RABONI, M.; TORRETTA, V.; URBINI G. Influence of strong diurnal variations in sewage quality on the performance of biological denitrification in small community wastewater treatment plants (WWTPs). Sustainability, v. 5, n. 9, p. 3679-3689, $2013 \mathrm{a}$. http://dx.doi.org/10.3390/su5093679

RABONI, M.; TORRETTA, V.; VIOTTI, P.; URBINI, G. Experimental plant for the physical-chemical treatment of groundwater polluted by municipal solid waste (MSW) leachate, with ammonia recovery. Revista Ambiente \& Agua, v. 8, n. 3, p. 22-32, 2013b. http://dx.doi.org/10.4136/ambi-agua.1250

RABONI, M.; TORRETTA, V.; VIOTTI, P.; URBINI, G. Pilot experimentation with complete mixing anoxic reactors to improve the performance of sewage denitrification in small communities treatment plants. Sustainability, v. 6, n.1, p.112-122, 2014a. http://dx.doi.org/10.3390/su6010112

RABONI, M.; TORRETTA, V.; VIOTTI, P.; URBINI, G. Calculating specific denitrification rates in pre-denitrification by assessing the influence of dissolved oxygen, sludge loading and the mixed-liquor recycle. Environmental Technology, v. 35, n. 20, p. 2582-2588, 2014b. http://dx.doi.org/10.1080/09593330.2014.913690

RABONI, M.; GAVASCI, R.; VIOTTI, P. Influence of denitrification reactor retention time distribution (RTD) on dissolved oxygen control and nitrogen removal efficiency. Water Science and Technology, v. 72, n. 1, p. 45-51, 2015. http://dx.doi.org/10.2166/wst.2015.188 
RUSTEN, B.; WIEN, A.; SKJEFSTAD, J. Spent aircraft deicing fluid as external carbon source for denitrification of municipal wastewater, from waste problem to beneficial Use. In: PURDUE INDUSTRIAL WASTE CONFERENCE, May 6-8 1996, Purdue. Proceedings... Purdue: Purdue University, 1996. p. 359-369.

SEYFRIED, C. F.; HIPPEN, A.; HELMER, C.; KUNST, S.; ROSENWINKEL, K. H. Onestage deammonification: nitrogen elimination at low costs. Water Science and Technology: Water Supply. v. 1, n. 1, p. 71-80, 2001.

SCHMIDT, I.; HERMELINK, C.; VAN DE PAS-SCHOONEN, K.; STROUS, M.; OP DEN CAMP, H. J.; KUENEN, J. G.; JETTEN, M. S. M. Anaerobic ammonia oxidation in the presence of nitrogen oxides $(\mathrm{NOx})$ by two different lithotrophs. Applied and Environmental Microbiology, v. 68, n. 11, p. 5351-5357, 2002.

STROUS, M.; HEIJNEN, J. J.; KUENEN J. G.; JETTEN M. S. M. The sequencing batch reactor as a powerful tool for the study of slowly growing anaerobic ammoniumoxidizing microorganisms. Applied Microbiology and Biotechnology, v. 50, n. 5, p. 589-596, 1998.

STROUS, M.; FUERST, J. A.; KRAMER, E. H. M.; LOGEMANN, S.; MUYZERT, G.; VAN DE PAS-SCHOONEN, K. T. et al. Missing lithotroph identified as new planctomycete. Nature, v. 400, p. 446-449, 1999. http://dx.doi.org/10.1038/22749

SUTTON, P. M.; MISHRA, P. N. Activated carbon-based biological fluidized-beds for contaminated water and wastewater treatment: A state-of-the-art review. Water Science and Technology, v. 29, n. 10-11, p. 309-317, 1994.

THÖLE, D. Presentation on MBBR system startup and performance. Ruhrverband: Department of Technical Management and Waste Management, 2007.

TORRETTA, V.; RAGAZZI, M.; TRULLI, E.; DE FEO, G.; URBINI, G.; RABONI, M.; RADA, E. C. Assessment of biological kinetics in a conventional municipal WWTP by means of oxygen uptake rate method. Sustainability, v. 6, n. 4, p. 1833-1847, 2014. http://dx.doi.org/10.3390/su6041833.

TCHOBANOGOLOUS, G.; BURTON, F. L.; STENSEL, H. D. Wastewater engineering: treatment and reuse. 4th ed. New York: McGraw Hill, 2003.

URBINI, G.; GAVASCI, R.; VIOTTI, P. Oxygen control and improved denitrification efficiency by means of a post-anoxic reactor. Sustainability, v. 7, n. 2, p. 1201-1212, 2015. http://dx.doi.org/10.3390/su7021201.

UNITED STATES. Enviromental Protect Agency - US-EPA. Wastewater management fact sheet -denitrifying filters. EPA 832-F-07-014. Whashington, 2007.

UNITED STATES. Enviromental Protect Agency - US-EPA. nutrient control design manual: state of technology, review report. EPA/600/R-09/012. Washington, 2009. $104 \mathrm{p}$.

UNITED STATES. Enviromental Protect Agency - US-EPA. Nutrient control design manual. EPA/600/R-10/100. Washington, 2010. 369 p.

VAN DONGEN, U.; JETTEN, M. S. M.; VAN LOOSDRECHT, M. C. M. The SHARON ${ }^{\circledR}-$ Anammox ${ }^{\circledR}$ process for treatment of ammonium rich wastewater. Water Science and Technology, v. 44, n. 1, p 153-160, 2001. 
VAN LOOSDRECHT, M. C. M.; JETTEN M.S.M. Microbiological conversions in nitrogen removal. Water Science and Technology, v. 38, n. 1, p. 1-7, 1998. http://dx.doi.org/10.1016/S0273-1223(98)00383-7

VIOTTI, P.; LUCIANO, A.; MANCINI, G.; TORRETTA, V. A wastewater treatment using a biofilm airlift suspension reactor with biomass attached to supports: a numerical model, International Journal of Environmental Science and Te, v. 11, n. 3, p. 571-588, 2014. http://dx.doi.org/10.1007/s13762-013-0256-6.

VIOTTI, P.; COLlivignARELli, M. C.; MARTORELli, E.; RABONI, M. Oxygen control and improved denitrification efficiency by dosing ferrous ions in the anoxic reactor. Desalination and water treatment, 2015.

http://dx.doi.org/10.1080/19443994.2015.1089200.

WETT, B.; NYHUIS, G.; TAKÁCS, I.; MURTHY S. Development of enhanced deammonification selector. In: WATER ENVIRONMENT FEDERATION, WEFTEC, 2-6 Oct. 2010, New Orleans. Proceedings... New Orleans, 2010. p. 5917-5926. http://dx.doi.org/10.2175/193864710798194139

WATER ENVIRONMENT RESEARCH FOUNDATION - WERF. Deammonification. Alexandria, 2014. 22 p.

WATER ENVIRONMENT RESEARCH FOUNDATION - WERF. Tertiary denitrification processes for low nitrogen and phosphorus. Alexandria, 2010. 26 p. 